\title{
The Practice of Village Governance: Comparing traditional form of Desa and Cultural Form of Nagari
}

\author{
${ }^{1}$ Muhammad \\ ${ }^{1}$ Universitas Islam Negeri Walisongo Semarang, Indonesia; muhammad@walisongo.ac.id
}

\begin{abstract}
Indonesia has been implementing a more in-depth decentralization system encouraging village governance since 2014. Since then, village governments have been given more autonomy on governing village funds to promote village development further. This paper aims to compare two forms of the Village (desa and nagari) in terms of the practice of village governance. This study mainly uses a qualitative descriptive method to compare the implementation of village governance in both traditional form (desa) and cultural form (nagari). With further Lowndes and Sullivan's analytical framework of neighbourhood governance, this study suggests all types of neighbourhood governance has been practiced in both forms. Although village government type is more significant in both forms, the social rationale is more significant in nagari because of the cultural aspect. Finally, based on the comparison of both forms of Village, this paper advocates some implications in the implementation of village governance.
\end{abstract}

Keywords: Village Governance; Desa; Nagari; Neighbourhood Governance

\section{Introduction}

In early 2014, Indonesian government established a new law about Village. This law confirms that Indonesian government has stepped further in the implementation of decentralization since the fall of the New Order. Previously in 2004, Indonesian government mandated decentralization to District/City Level (Antlöv et al., 2016). However, the new law is believed to be inspired by PNPM (Community Empowerment Program) ran by an independent agency under the national government to speed up development in Indonesian villages (in Wahyudi Soeriaatmadja, 2014). The PNPM ran from 2009 until 2014. Similar with PNPM, Village government is given with financial autonomy to manage a certain amount of budget given by the National government. Village government, which previously was the lowest administrative agency under District Government, now has a unique position. It is still an administrative agency yet also acts as government entity that can plan its own policy, as well as implement and evaluate its budget expenses. This confirms that Indonesia has implemented double devolution in its decentralization system enabling Village to make its own governance.

However, the implementation of village governance in terms of decentralization is not without problems and challenges. Despite the success stories of many villages carrying out development in their areas, there are many village governments who are still struggling delivering improvements and developments for their people. Various problems regarding the recent practice of village governance emerged complicating the development of the villages themselves. Firstly, the development plan of village government and higher level governments is not yet well integrated (Zamroni et al., 2015). On the other hand, the performance of the 
village council in carrying out its functions is still considered low in many villages due to low capacity of its members in understanding and performing their roles in village government (Bachtiar, 2016). Another challenge is that village-owned enterprise orientation is financial benefit, neglecting its role in delivering public service (Matutu, 2016). In addition, village capacity to bring village-owned enterprise to be successful is still low in many villages (Matutu, 2016). Furthermore, the question remains regarding participation of common citizens in the village governance, are they really empowered by exercising their voice and choice and their role on holding authorities accountable, or again, it is only the community elites that performs such roles (Mariana, 2017). Lastly, the cultural and social aspects are different across villages in Indonesia. Further uniformity of village governance may result in more complicated problems.

Therefore, further study needs to be conducted to analyze the practice of village governance. However, many research discussing a village governance in Indonesia are more focused on one type of Village or Village in general. There has not been any research comparing the two existing forms of Village in Indonesia. Hence, this study is essential in comparing both forms of Village in Indonesia. Comparing the two existing forms of Village in Indonesia may illuminate some beneficial insights in terms of the governance.

This study seeks to analyze to what extent village governance has been practiced in the two forms of Village in Indonesia; traditional form of desa and cultural form of nagari. It further questions the application of four types of neighbourhood governance proposed by Lowndes and Sullivan, village partnership, empowerment, management, and government, in both villages. Lowndess and Sullivan's framework has been used by many research to analyze neighbourhood governance. However, this framework has not been used in analyzing the form of Village in Indonesia. This study demonstrates that the four types of neighbourhood governance can be exercised within single platform of village governance. Though, further findings show that the village government type is prominent due to special village budget allocation. Furthermore, cultural aspect, as expected, has much influence in traditional Village like Nagari Sungai Duo making the partnership's social rationale stronger than typical Village like Bantarsari. However, as much as it has many potentials, the new village governance also has challenges to overcome.

\section{Village Governance}

Neighborhood governance has been acknowledged as an excellent alternative of public governance. Several motives can be identified to justify neighborhood governance. Government's program in enacting neighborhood governance might be a strategy of containment (Pill and Bailey, 2012). As in Indonesia, it can also become political commodity because it can appeal broader public to win election. However, as Lowndes and Sullivan suggest, the importance of neighborhood governance could be based on four rationales; civic, social, political, and economic. The following table points out some aspects of the four rationales. 
Table 1

Lowndes and Sullivan's Framework of Neighborhood Governance

\begin{tabular}{|c|c|c|c|c|}
\hline & $\begin{array}{l}\text { Neighborhood } \\
\text { Empowerment }\end{array}$ & $\begin{array}{l}\text { Neighborhood } \\
\text { Partnership }\end{array}$ & $\begin{array}{l}\text { Neighborhood } \\
\text { Government }\end{array}$ & $\begin{array}{l}\text { Neighborhood } \\
\text { Management }\end{array}$ \\
\hline Primary rationale & Civic & Social & Politic & Economic \\
\hline Key objectives & $\begin{array}{l}\text { Active citizens and } \\
\text { cohesive } \\
\text { communities }\end{array}$ & $\begin{array}{l}\text { Citizen well-being } \\
\text { and regeneration }\end{array}$ & $\begin{array}{l}\text { Responsive and } \\
\text { accountable } \\
\text { decision-making }\end{array}$ & $\begin{array}{lr}\text { More } & \text { effective } \\
\text { local } & \text { service } \\
\text { delivery } & \end{array}$ \\
\hline Democratic device & $\begin{array}{l}\text { Participatory } \\
\text { democracy }\end{array}$ & $\begin{array}{l}\text { Stakeholder } \\
\text { democracy }\end{array}$ & $\begin{array}{l}\text { Representative } \\
\text { democracy }\end{array}$ & Market democracy \\
\hline Citizen role & Citizen: voice & Partner: Loyalty & Elector: vote & Consumer: choice \\
\hline Leadership role & Animateur, enabler & Broker, chair & $\begin{array}{l}\text { Councilor, mini- } \\
\text { mayor }\end{array}$ & $\begin{array}{l}\text { Entrepreneur, } \\
\text { director }\end{array}$ \\
\hline Institutional forms & $\begin{array}{l}\text { Forums, } \\
\text { Co-production }\end{array}$ & $\begin{array}{l}\text { Service board, } \\
\text { mini-LSP }\end{array}$ & $\begin{array}{l}\text { Town councils, area } \\
\text { committees }\end{array}$ & Contracts, charters \\
\hline
\end{tabular}

Source: Lowndes and Sullivan (2008, p. 62)

As the Table 1 shows, there are four possible types of neighborhood governance that are based on the four rationales. Firstly, by establishing forums and co-productive activities Neighborhood empowerment focus to develop active citizens and cohesive communities. Meanwhile, Neighborhood partnership's objectives are citizen well-being and regeneration. The next type is neighborhood government which aims to develop more responsive and accountable decision making in a council or area committee. Lastly, Neighborhood management uses mechanisms such as contracts and charters to deliver public service more effectively (Lowndes and Sullivan, 2008).

Nonetheless, neighbourhood is possible to become base of public governance because it has appealing caracteristics. Neighbourhood is not only about a group of people living in a certain area with basic fasilities. More than that, neighborhood has a social aspect in which people develop collective identities, mutual interactions, and a supportive attitude (Lowndes and Sullivan, 2008). Similar characteristics are also evident at the village level in Indonesia, especially in the rural areas. Therefore, the concept of neighbourhood governance can be applicable in Indonesian village governance.

\section{The Changing Regulation on Village in Indonesia}

The village governance in Indonesia has been changes several times. The first form of governing Village was in highly centralized system which was before 1999. Village was considered the lowest territorial government under sub district office. It serves the national government as the frontline of government service and data collection. It was managed fully top down through regulations and reports. However, based on the existing culture of 'desa', the chief was directly elected but strictly accountable to higher level government. The village form and function in this stage was uniform across the nation. 
After decentralization has been implemented since the establishment of Law 22/1999 on Regional Government, the village status changed. Here, Village was considered a legal community in a district territory. Instead of 'desa', local names were established in many villages, such as Banjar in Bali, Kapitalaung in Sangihe, North Sulawesi, and Nagari in West Sumatra. In addition, the village council was established in every Village, making the directly elected village head accountable to it.

The regulation on Village was then slightly changed by the special regulation on villages in 2005, after a new regulation on regional government was introduced in 2004. Here, the village legislation needed to be approved by the district government. Furthermore, a bottomup development planning forum was introduced involving the village council and authorities and broader village community representatives. The meeting was held in sequence from the lowest legal territory: Village, sub-district forum, district forum, and provincial forum to the national meeting. Other than that, the aspects of village governance were similar to the previous arrangement.

However, even after this much decentralization, the village development was still unsatisfactory. Decentralization focus on district government made its development focus was general, far from what the Village needs. Village development was slow, especially those which are located far from the district government office. The development planning forum was just ceremonial. Less and less public is involved because there was not much change even after the annual forum was held.

Therefore, a new program was implemented, namely PNPM (a community-based development). It focuses more on community participation in every aspect of development project, including planning, implementation, and evaluation. It was implemented starting from 1999 until 2013 mainly directed to boost village development. It was considered a successful program because it made many achievements in village development that suited each village's need. Still, its approach has also increased public participation and awareness of the importance of transparency and accountability of their local governments.

Learning from this achievement of PNPM, the government put decentralization further to be implemented in Village. As a result, development based on village community initiatives proved to be more effective than classical top-down development. Indeed, Indonesia has put decentralization on the district level. To some extent, it has brought some significant developments in many district regions. However, many villages are still less developed. Furthermore, this kind of program has become a political commodity as well. The current president is the one who promised further implementation of this program during an election campaign. Therefore, because such a program is beneficial and the president won the election, the Village law then passed the legislation.

The main feature of the new village law is about the village budget. Villages are now allocated special budget not only from the national budget but also from local government budget. The new village law requires that $10 \%$ of the national budget should be allocated and distributed to villages to be managed autonomously. Local governments should also allocate $10 \%$ of their budget to villages. Villages will also get a portion from local tax revenues. Some villages, especially those in remote areas, will also get the special budget from the ministry of Village and transmigration as the subject of special program from the ministry. The ministry of Village also employs village facilitators to help villages to manage the budget effectively. Local governments are also necessary to give villages assistance. Hence, villages are expected to be more effective and efficient in carrying development programs for the community's sake. 
Therefore, the new village law incorporates previous aspects of village governance and enhances it by the economic aspect of the village budget. The four rationales introduced by Lowndes and Sullivan therefore evident in the new village law. First, the civic rationale of village governance is manifested by the establishment of an annual development planning forum. In that forum, community representatives are mandatory and open for the public as well. Therefore, citizens can exercise their voice and choice of village development. Second, the political rationale is evident by the existence of the village council and even the direct election of the village head so that the village government can be held accountable. Third, the social rationale was also present by the development project of the Village mandated by the State. Lastly, Economic rationale is manifested financial autonomy so that village community can manage public service and development more efficiently and effectively. Therefore, different types of neighbourhood governance are exercised in the new village law.

\section{Method}

This study uses a qualitative descriptive method to extensively analyze and compare the practice of village governance of two villages. The first Village is Bantarsari. Bantarsari is a typical rural village which is located in Bogor, West Jawa Province, a district near the capital city of Indonesia, Jakarta. The second Village is Nagari Sungai Duo. It is a traditional village that has special characteristics that are recognized by the new village law. Nagari Sungai Duo is located in rural area of Darmasraya, West Sumatra.

This study further uses Lowndes and Sullivan's analytical framework of neighbourhood governance. It will particularly explore the manifestation of the four types of neighbourhood governance in both villages. However, this research is limited to using only some online materials. The primary data sources to analyze the village governance practice of both villages are the Annual village budget. The Annual village budget of Bantarsari village that is available online in the village budget 2015. On the other hand, Nagari Sungai Duo already has its village budget 2016 in its official online publication.

\section{Nagari, a cultural form village in West Sumatra}

Nagari is originally a cultural entity considered the smallest community governance in Minangkabau culture in West Sumatra. It consists of its social structure with its own function. Minang People are organized culturally based on their kinship. Thus, some families will form a Jorong, and some jorong forms a Nagari, distinct community governance. Cultural chiefs govern it in the platform Kerapatan Adat Nagari (KAN).

Because its formation and function resemble the modern form of Village, some of them were used by previous governments since Dutch colonial government until now, as the base of village region. However, in the era of Suharto's new order (reigned from 1966 until 1998), there was a generalization of village form and function, which resulted in eradicating the traditional form of community replaced by government-designed Village with its region and function. Therefore, cultural communities across Indonesia were transformed and modernized into tightly controlled villages. However, the cultural practice was preserved in different ways. Some legal institutions such as Badan Perwakilan Anak Nagari BPAN were made to accommodate these communities. As the result, there has been dual institutions governing Minang people. Politically, they were governed in the village region, but culturally they are governed by cultural institutions. 
After, Suharto regime, governance reformed occurred resulted in the change on village governace. That is because Minang People's movement advocating to return to Nagari system as a legal, political and cultural entity. The same demand also raised from different regions such as Bali. Therefore, the gradual change occurred between 1999 until 2014. The first one was the nomenclature change, which allowed villages to change the name of Village from 'desa' into something else. In the case of West Sumatra, the title 'desa' has transformed into Nagari. However, there has no significant systemic change in territory nor function.

Finally, the village law 2014 allows villages to change their status as a cultural village with different consequences. First, it means that Nagari, already established, can become the cultural Village. Based on recent data there are 754 Nagari spread across 12 Regencies in the West Sumatra province, and all of them are with the status of cultural Village. The status of cultural Village means that the National government gives such village recognition of at least in three aspects. The first aspect is the original cultural village structure, including cultural authorities and their roles in societies. The second aspect is cultural norms, values, and rules that govern the society. Lastly, State also recognizes the cultural rights of such communities, including the communal land that belongs to the society. Finally, it means that the law has recognized autonomous villages in the national territory.

However, this significant change on Village law does not necessarily mean that communities returned to the original Nagari system. The administrative matters have been long taken care of by village authorities run by government-designed 'desa' as the civil public service and street-level bureaucrat, administering government programs on communities. Cultural suppression that the Suharto regime had conducted for 32 years resulted in the change in the culture itself. Furthermore, it will be more complicated to turn the existing village system entirely into something else no longer recognized by today's generation. Therefore, Nagari system now is trying to combine both modern government administration with the cultural institution. The following figure shows the combination of administrative government and cultural structure.

Figure 1

Structure of Nagari

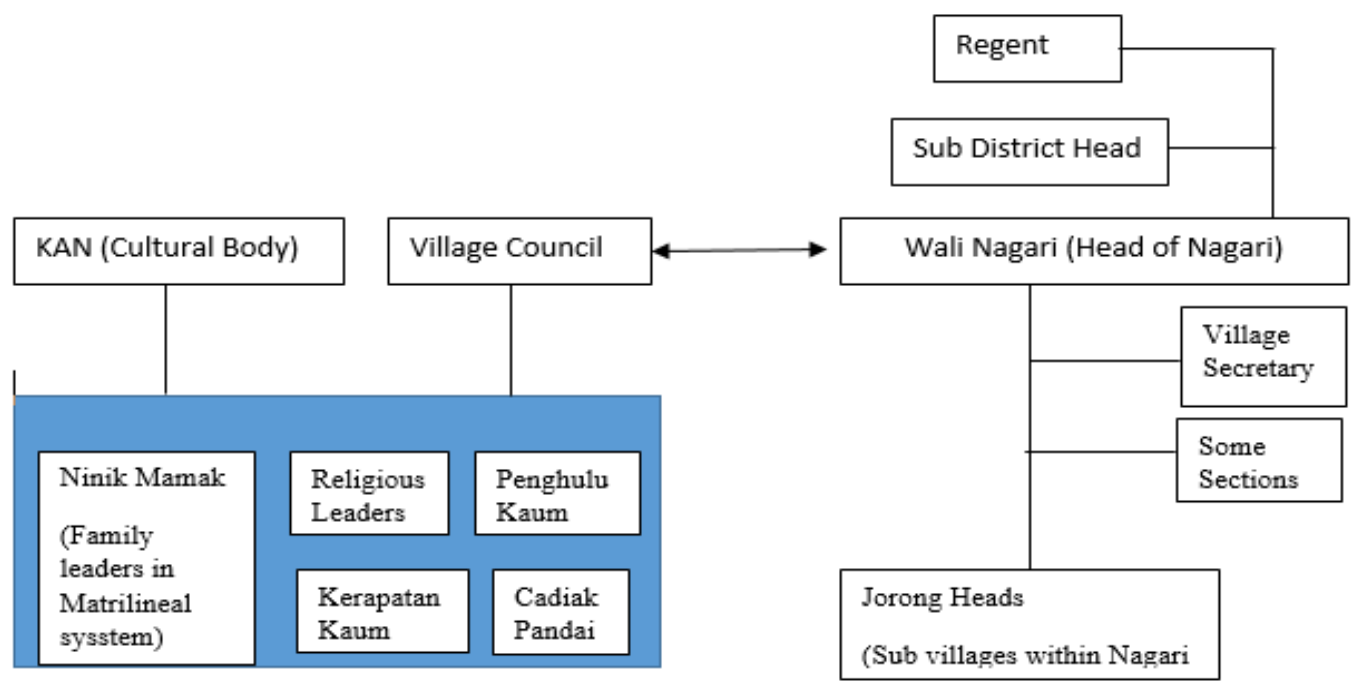


As the figure 1 shows, the cultural element of society become more robust in governance. The cultural structure of Minang indeed has already existed as a legal institution, namely BPAN and KAN. Even though they are separated from the government, these two institutions have long been involved in the development planning forum because it is required to involve community representatives. However, the cultural structure now has an essential position in village governance as it sits in village council and village assembly. Therefore, the cultural sense becomes more vital because the village head that is recently named 'wali nagari' is about the government's authority and one of the leaders in cultural structure.

However, restructuring villages into Nagari is not without problem. As discussed before, while Nagari is a cultural community, Village is considered a governmental entity in terms of 'desa'. Practically, some villages have the same territory as Nagari. Therefore, it is easy to change the status 'desa' into Nagari. On the other hand, some Nagari has a more expansive environment than governmental villages have. Some Nagari can consist of several villages. Some Nagari even has a territory similar to what a sub-district has. The transformation of 'desa' into Nagari in those cases is undoubtedly problematic. There will be a unification of governmental Village, 'desa'. Furthermore, the problem also poses a pain in the allocation of the village budget by the local government. Therefore, the local government has to consider some differences in territory and population.

\section{Results and Discussion}

\section{Village Management of both Desa Bantarsari and Nagari Sungai Duo}

As discussed before, the village budget is the main distinguishing feature of the new village law. Villages are given a certain amount of funding to be managed autonomously. According to the law, Villages are independent from the higher-level government in spending the annual budget. However, this given village budget comes with some responsibilities and accountabilities. Villages are expected to plan and implement public service and village development more effectively and more efficiently. Village governments are considered to understand the circumstances and resources of the Village and the interests of village communities. Therefore, Villages can then assess, access, and purchase what is needed for the village development independently with that financial resource.

In the case of Desa Bantarsari, the village management was fulfilling the expected economic rationale. The Village established not only an annual action plan but also long-term plan. Furthermore, based on the village budget 2015, the village budget was primarily spent on basic community infrastructures such as village roads and pathways, sanitation, and village building rehabilitation. The Village also facilitated the need of most of its citizens who work as farmers by building and rehabilitating irrigation canals. The health service in Bantarsari was also improved by purchasing an emergency vehicle because the Village's location is in a rural area that is quite far from a nearby city. This demonstrates that the Bantarsari village has implemented excellent village management as expected from the economic rationale.

Another economic element of the Bantarsari village is the BUMDes (village-owned enterprise). This is meant to create additional income for the village budget. For that, the village authorities need to assess some potentials that can be valuable resources for the Village. Therefore, Bantarsari village established an agro-tourism business. This was based on the fact that most of the citizens work as farmers. However, there is no report on how this villageowned enterprise is managed. Therefore, it appeared that the agro-tourism business had not 
made any profit for the Village because there is no additional income in the village budget report in 2015.

Similar to Bantasari village, the Village management of Nagari Sungai Duo follows the typical village platform. Nagari Sungai Duo also established an annual action plan as well as long term plan. Most of the village budget was also spent on community infrastructures. Some of the recorded infrastructures in the annual report 2016 were rehabilitating roads, pathways, drainages, bridges, and village office buildings. The health and education service were also improved by building Nagari's health centre and playgroup. Supported by village budget allocation from higher-level governments, Nagari Sungai Duo has implemented excellent village management as expected from economic rationale, providing public service and delivering development projects more effectively and efficiently.

BUMNag (Nagari-owned enterprise) was also established in Nagari Sungai Duo. In 2016, it invested around 3\% of the total budgets for establishing the enterprise. Different from Bantarsari, Nagari Sungai Duo could generate additional income for the village budget. It contributed around $6 \%$ of the total village budget in 2016. Although the amount of the payment is not that big to help financing Nagari's development, it has showed that it contributed to the financial autonomy of the Nagari Sungai Duo.

\section{Village Government of Desa Bantarsari and Nagari Sungai Duo}

Generally, village government in every Village including Bantarsari complies the assigned platform mandated by the law. The typical elements of village government mentioned by Lowndes and Sullivan are evident, especially in Bantarsari village. Citizens directly elect a village head. There is also a village council which the role is similar to the legislative body in a presidential system. The members of the village council are also directly elected by the citizens. Therefore, both the village council and village head elections facilitate the village citizens to hold village authorities accountable.

However, even though every Village has a similar structure, to what extent the village government has functioned is undoubtedly different. In the case of Bantarsari village, the village government appear to be fulfilling the political rationale. The village government has recognized the need and aspirations of farmers and responded to them by managing irrigation development. The irrigation development and other projects were also well documented in the report and online publication, making it more accountable.

Meanwhile, although Elements of Village government prescribed by Lowndes and Sullivan are evident in Nagari Sungai Duo, the implementation is somewhat different. The village head, which is called Wali Nagari, is indeed directly elected. However, candidates of Wali Nagari should be approved by the cultural leaders of Nagari. Figure 1 shows that the members of the council are all from cultural leaders. Therefore, they are not directly elected as typical Villages in Indonesia. However, Ninik Mamaks, the woman who is in the highest position of the big family, is also a council member. Therefore, it is still considered representative to the broader community in Nagari. Furthermore, both election mechanism and the council have the same role as other typical villages in Indonesia to keep village government accountable.

Furthermore, even though cultural aspects of Nagari have much influence on Nagari government, it does not impede the Nagari's function and role to fulfil the political rationale of village government. Political aspiration is accommodated through a different route through a family representative, the Ninik Mamak. Especially in Nagari Sungai Duo, the government's 
activities and projects are well documented in the report and online publication, making it more accountable.

\section{Village empowerment of Desa Bantarsari and Nagari Sungai Duo}

Like the village government, there is also a general platform for every Village in terms of how village authorities perform village empowerment. Besides the village council, citizens can also exercise their choice and voice through the annual development planning forum. This activity was evident in the financial report of Bantarsari village. The meeting was not only about development planning but also about the public evaluation of village development projects. Therefore, citizens voice matters in this forum. Citizens' choice was also critical in this forum because it helped village authorities to arrange development priorities. Furthermore, because the Village now has financial autonomy, the development priorities of Bantarsari can be implemented using the village budget. The annual budget report showed that the implementation of development priorities suggested by the forum was evident.

Village empowerment in Bantarsari village was also manifested in other aspects. Bantarsari farmers produce most of the guava in the region. When harvest time, the number of guavas is abundant. Therefore, to support the agro-tourism business and increase the economic capacity of farmers in Bantarsari, women in the farmer families participated in the workshop to process guava into other products that last longer, such as crackers. The infrastructure development project also employed local citizens so that they can have additional income. Thus, Village empowerment in Bantarsari has fulfilled the civic rationale of village governance.

On the other hand, the manifestation of village empowerment of Nagari Sungai Duo is slightly different in the aspect of the village council. Indeed, it does limit citizens' choice on who deserves to be the village council members, but that does not mean that it impedes citizens' voice of aspiration toward the village council. Furthermore, in this Nagari structure, empowerment is associated with cultural aspects. Cultural leaders that were previously suppressed are now encouraged to perform more to return cultural norms, values, and rules to Minang society. This kind of effort is evident in some legal Nagari regulations.

Besides the cultural aspect, the manifestation of village empowerment in Nagari Sungai Duo is just similar to other typical villages. Firstly, citizens of Nagari Sungai Duo can exercise their voices and choices through the development planning forum, just the same as any other village. This activity was evident in the village budget document of Nagari Sungai Duo in 2016. Moreover, just like Bantarsari, the financial autonomy of Nagari has implemented development priorities suggested by the forum as possible. Therefore, financial independence impacted not only village management but also village empowerment. Secondly, the manifestation of village empowerment in Nagari Sungai Duo was also found in many capacity building programs for citizens such as computer training for youths, tailor training for women, and workshops for teachers of religious schools. Therefore, the civic rationale of village empowerment is also evident in the Nagari system.

\section{Village Partnership of Desa Bantarsari and Nagari Sungai Duo}

Different from other types of village governance, there is no typical platform for village partnership. In Bantarsari village, one village partnership was manifested in establishing a village-owned enterprise, the agro-tourism business. The partnership was built between the 
village government and the farmer association in the Village. Later, the partnership can also be built with PKK (women association) in the Village to support agro-tourism business with guava products.

Other village partnerships were also evident in the village programs reported in the annual budget report. For example, the purchasing of emergency vehicles and the rehabilitation of village health centres are coordinated with village midwives and doctors. There were also religious programs and activities reported in the annual budget report, which was coordinated with religious leaders. These showed that the social rationale for improving citizens' wellbeing in the Bantarsari village partnership was evident.

Unlike Desa Bantarsari, the manifestation of village partnership in Nagari is related to the cultural aspect itself. Through the new village law, the State acknowledges this social rationale by creating a different cultural Village. It means that the State recognises the capability of the traditional set of norms and rules to govern its own community. Therefore, the State creates this kind governance partnership with the traditional society to carry out public governance as part of national governance. Thus, the establishment of Nagari as part of national public governance is a partnership form between the state and traditional community.

However, the traditional set of norms and rules are not prominent in the public governance of Nagari including in Nagari Sungai Duo. In fact, Cultural leaders do not automatically become the leader of the village government. As discussed before, Minang people had long been suppressed culturally. There are forms of uniformity in every aspect of public governance that gradually change their culture and their ways of governing communities. Minang People in this generation knows that they have distinct set of values and norms, but do not necessarily know the original form of community governance. Minang people get used to the form of typical public governance. Therefore, Dualism is evident in the village structure and how they manage and allocate the village budget.

Unlike typical Village like Bantarsari, the village budget realization in Nagari has a fair balance allocation between physical development and social development. In fact, some physical developments also directed to the rehabilitation of cultural and religious buildings. Furthermore, most of the social development goes to the revitalization of Minang culture and religious activities. Religious activities are entirely supported because historically and substantially, Minang culture has a close relationship with Islamic values.

The implementation of social development by performing Minang culture and religious activities also reflect forms of partnership in Nagari Sungai Duo. To carry out the revitalization of Minang culture, partnership is indeed necessary between village authorities and cultural leaders. The same goes to the implementation of religious programs in Nagari Sungai Duo. Based on the Village budget report 2016 of Nagari Sungai Duo, Other social organizations such as the women association and youth association were also engaged in carrying out some of the village development programs. Therefore, the social rationale of village partnership is also evident in the village governance of Nagari Sugai Duo.

\section{Conclusion}

The implementation of village governance in both Bantarsari village and Nagari Sungai Duo is not that different. Because of the village budget allocation, village development was carried out effectively and efficiently by both villages. As expected, Village governance of Nagari has more cultural aspects than in a typical Village like Bantarsari. However, the cultural element does not seem to influence an everyday part of village governance. Dualism indeed 
occurs in the structure and social programs, but Nagari is a more government agent than a traditional community governed by traditional rules and norms. Nonetheless, the new cultural village arrangement has made the revitalization of Minang culture possible by exercising village partnership and village empowerment.

The four types of village governance are indeed practised in both Bantarsari Village and Nagari Sungai Duo. Institutions and governance mechanisms characteristics of the four types of village governance are evident in both Villages. However, many of the institutions and the practices of the village governance have already been prescribed by the laws before the new village law 2014. For example, direct election of a village head, village council, social organizations in the Village, and development planning forum was already in place before establishing the new village law. However, all of them were not fully effective to carry out village development until the new village law was activated.

The establishment of a special village budget allocated by the national government and local government makes the exercise of village governance possible. The financial resource has given both villages capability to carry out local initiatives. It also encourages villages to utilize their assets and explore their village potentials. Furthermore, community representatives have more consciousness of their voice and choice in the development planning forum. That is because the available village budget can execute development priorities. They are also more conscious of their roles in holding village authorities accountable. Therefore, all four rationales are empowered by the new village law arrangements.

However, while in general, village institutions have been structured to support traditional forms of village government, cultural conditions such as Nagari need a more flexible structure than public institutions in terms of roles and rules in governing the society within the Village. Discretion and flexibility are also principal in the use of the village budget mandated by the higher-level government. The prosperity of society is measured by physical aspects such as infrastructure and other aspects such as social values, the continuation of cultural tradition, and so on. Therefore, Village, whether in traditional or cultural forms, should be given more trust and guidance in governing their issues. The intervention of higher-level government in village governance by establishing more regulations and distributing village consultants could be empowering or unnecessarily confining. Therefore, both village consultants and regulations should be flexible depending on the village capacity on performing village governance.

This study has discussed village governance in Indonesia after the new village law was established in 2014. It indicates that the four types of neighbourhood governance proposed by Lowndes and Sullivan are evident. As expected, the management type is prominent and socialcultural rationale influences traditional Villages like Nagari. However, this study also has suggested that although the application of the new village governance generates many benefits for citizens, it still has room for improvements. Nonetheless, this study has demonstrated that the theoretical framework proposed by Lowndes and Sullivan helps evaluate the implementation of village governance, especially in Indonesia. However, further study needs to be conducted to incorporate more field-work evidence from more villages to evaluate citizens' participation and well-being, especially after implementing the new village law. 


\section{References}

Antlöv, H., Wetterberg, A. \& Dharmawan, L. 2016. Village Governance, Community Life, and the 2014 Village Law in Indonesia. Bulletin of Indonesian Economic Studies, 52, 161183.

Bachtiar, P. P. 2016. Membenahi BPD untuk Memperkuat Desa [Online]. SMERU. Available: http://www.smeru.or.id/sites/default/files/publication/pbbenahibpd.pdf [Accessed April 21st 2017].

Lowndes, V. \& Sullivan, H. 2008. How Low Can You Go? Rationales And Challenges For Neighbourhood Governance. Public Administration, 86, 53-74.

Mariana, D. 2017. Merawat Demokrasi Lokal untuk Transformasi Ekonomi Desa [Online]. Yogyakarta:

IRE.

Available:

http://ireyogya.org/uploads/PB\%20IRE\%20Merawat\%20Demokrasi\%20Lokal\%20un tuk\%20Kesejahteraan_Dina\%20Mariana\%209052017.pdf [Accessed June 5th 2017].

Matutu, S. D. B. 2016. Mengembangkan BUMDesa untuk Transformasi Ekonomi Desa [Online]. Yogyakarta: IRE. Available: https://ireyogya.org/uploads/PB\%20IRE\%20BUMDesa\%2010062016\%20OK.pdf [Accessed April 20th 2017].

Pill, M. \& Bailey, N. 2012. Community Empowerment or a Strategy of Containment? Evaluating Neighbourhood Governance in the City of Westminster. Local Government Studies, 38, 731.

Wahyudi Soeriaatmadja In, J. 2014. Villages in Indonesia cash in on new law: Big shift in spending from cities to rural areas gives rural leaders more clout. The Straits Times, p.Newspaper Article.

Zamroni, S., Anwar, Z. \& Mariana, D. 2015. Mengintegrasikan Perencanaan Pembangunan Desa [Online]. Yogyakarta: Institute for Research and Empowerment. Available: https://ireyogya.org/uploads/PB\%20Mengintegrasikan\%20Perencanaan\%2009012015 \%20FINAL\%20SIAP\%20CETAK-2.pdf [Accessed April 20th 2017]. 